\title{
Registratielast: waar komt het vandaan?
}

De registratielast die verpleegkundigen, verzorgenden, praktijkondersteuners en begeleiders ervaren, krijgt veel aandacht in media, beleid en onderzoek. Tot nu toe is de aandacht vooral gericht op registratiewerkzaamheden die zorgprofessionals doen voor organisaties, zoals minutenregistraties of declaraties. Maar uit ons onderzoek blijkt dat zij ook registratielast ervaren door de verslaglegging over de zorg aan individuele cliënten.

auteurs

KIM DE GROOT onderzoeker Nivel, wijkverpleegkundige Thebe

Wijkverpleging

WIM VEREST

onderzoeker Nivel

ANKE DE VEER

senior onderzoeker Nivel

\section{WOLTER PAANS \\ lector Verpleegkundige Diagnostiek \\ Hanzehogeschool Groningen}

\section{ANNEKE FRANCKE} programmaleider Nivel, bijzonder hoogleraar

'Verpleging en verzorging in de laatste levensfase'

Amsterdam Public Health onderzoeksinstituut,

Amsterdam UMC, locatie VUmc
$\mathrm{V}$ ERPLEEGKUNDIGEN, VERZORGENden, praktijkondersteuners en begeleiders besteden veel tijd aan registratietaken, wat ten koste gaat van tijd voor zorg aan cliënten. Deze zorgprofessionals zeggen dan ook al jaren dat het verminderen van de registratielast een belangrijke maatregel is om hun beroep aantrekkelijker te maken. ${ }^{1}$ Toch blijven registratietaken veel tijd kosten en neemt de werkdruk volgens de zorgprofessionals verder toe., ${ }^{2,3}$ Wat is nodig om het tij te keren? Hiervoor is het belangrijk verder naar de oorzaken van het probleem te kijken en ook onderscheid te maken in soorten registratietaken.

\section{Verschillende registratietaken}

Registratie is een containerbegrip waar een veelvoud aan taken onder valt. Registratietaken kun je indelen in twee groe- pen: (1) de verslaglegging over de zorg aan individuele cliënten en (2) het registreren van informatie voor organisaties, management en/of beleid (organisaties). Bij de eerste groep kun je denken aan de verslaglegging in zorg(leef)plannen, het schrijven van rapportages over de zorg aan individuele cliënten en het maken van overdrachten. Onder de tweede groep vallen taken zoals het registreren van gewerkte uren of declaraties, het registreren van informatie voor kwaliteitskeurmerken en het invullen van formulieren voor aanvragen van hulp- of verbandmiddelen.

\section{Wat kost de meeste tijd?}

In ons onderzoek vroegen we verpleegkundigen, verzorgenden, praktijkondersteuners en begeleiders hoeveel tijd zij besteden aan de registratietaken. De meeste tijd van deze zorgprofessionals zit in de verslaglegging over de zorg aan individuele cliënten; zij besteden hier gemiddeld 6,4 uur per week aan. Daarnaast besteden zij gemiddeld 3 uur per week aan de registratiewerkzaamheden voor organisaties. Ze zijn dus in totaal ongeveer 9,5 uur kwijt aan registratietaken, terwijl zij gemiddeld 26 uur per week werken. Slechts een kwart is het dan ook eens met de stelling: 'De hoeveelheid tijd die ik besteed aan administratief werk is redelijk en ik weet zeker

\section{FIGUUR 1 HOE VAAK ERVAREN ZORGPROFESSIONALS VERHOOGDE WERKDRUK DOOR VERSLAGLEGGING OVER ZORG AAN INDIVIDUELE CLIËNTEN?}

$2.8 \%$

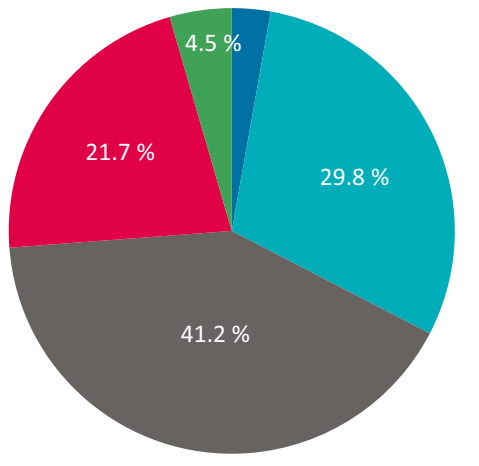

nooit

चelden

regelmatig

vaak

altijd 
dat de cliënten er niet onder te lijden hebben'. Bijna de helft van de zorgprofessionals is het (zeer) oneens met deze stelling.

\section{Wat geeft de meeste werkdruk?}

Dat zorgprofessionals de meeste tijd besteden aan de verslaglegging over de zorg aan individuele cliënten hoeft niet te betekenen dat dit ook de belangrijkste oorzaak is van de registratielast. Er is namelijk een verschil tussen de objectieve tijd die je besteedt aan een taak en de subjectieve last die je ervaart bij het uitvoeren ervan. Zo liet eerder onderzoek zien dat de ervaren registratielast door vele factoren wordt beïnvloed. ${ }^{4}$ Niet alleen door de tijd die zorgprofessionals daadwerkelijk besteden aan de registratietaken, maar bijvoorbeeld ook door het gevoel dat zij hebben dat de organisatie er alles aan doet om de registratietaken te beperken. ${ }^{4}$

We vroegen zorgprofessionals hoe vaak zij een verhoogde werkdruk ervaren ten gevolge van de registratietaken. Hier blijkt dat beide groepen registratietaken er bijna even vaak voor zorgen dat zorgprofessionals een verhoogde werkdruk ervaren. Bij verslaglegging over de zorg aan individuele cliënten ervaart 67 procent regelmatig tot altijd een verhoogde werkdruk, bij de registratiewerkzaamheden voor organisaties 62 procent (zie figuur 1 en 2).

\section{Gebruiksvriendelijkheid dossiers}

Het is een opvallende uitkomst dat de verslaglegging over de zorg aan individuele cliënten in gelijke mate zorgt voor verhoogde ervaren werkdruk als de registratiewerkzaamheden voor organisaties. Verslaglegging is namelijk onderdeel van de kern van de beroepsuitoefening: het verlenen van zorg aan individuele cliënten.
Wat maakt dat zorgprofessionals ook een verhoogde werkdruk ervaren door verslaglegging over de zorg aan individuele cliënten? De opbouw van de huidige elektronische dossiers speelt hierbij een rol. Uit de praktijk en eerder onderzoek is bekend dat zorgprofessionals dezelfde informatie over een individuele cliënt nu meerdere keren vastleggen. Bij overdracht van een cliënt naar een andere zorgorganisatie wordt dezelfde informatie zelfs tot zeven keer overgetypt door zorgprofessionals. ${ }^{5}$ Uit ons onderzoek blijkt dat zorgprofessionals significant minder vaak een verhoogde werkdruk ervaren wanneer zij werken met een gebruiksvriendelijk elektronisch dossier. Daarnaast wordt significant minder vaak een verhoogde werkdruk ervaren door zorgprofessionals die vinden dat het verpleegkundig proces centraal staat in hun elektronisch dossier.

\section{Hoe verder?}

Tot nu toe richten de maatregelen om de registratielast te verminderen zich vooral op het terugdringen van registratiewerkzaamheden voor organisaties. Zo is het ministerie van VWS in 2018 gestart met het programma '(Ont)Regel de Zorg.' Hieruit volgen veel verschillende acties, zoals schrapsessies, afschaffen van minutenregistraties en landelijke afspraken over het eenvoudig aanvragen van hulpmiddelen. Gezien de tijd die zorgprofessionals besteden aan de registratiewerkzaamheden voor organisaties, is dit programma belangrijk voor het verminderen van de registratietaken.

Om het probleem van de registratielast grondig aan te pakken, is het ook belangrijk dat zorgprofessionals bij de verslaglegging over de zorg aan individuele cliënten

\section{FIGUUR 2 HOE VAAK ERVAREN ZORGPROFESSIONALS VERHOOGDE WERKDRUK DOOR REGISTRATIEWERKZAAMHEDEN VOOR ORGANISATIES?}

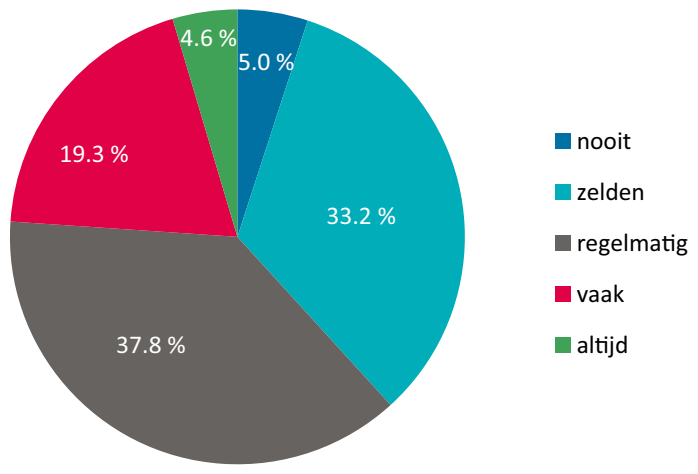

worden ondersteund door gebruiksvriendelijke elektronische dossiers, die aansluiten bij de fasen van het verpleegkundig proces. Het is belangrijk dat de informatie uit de dossiers uitwisselbaar is tussen zorgorganisaties. Dit vraagt om een verbetering van de huidige elektronische dossiers. Daarnaast is het belangrijk aan zorgprofessionals te blijven vragen of de maatregelen die zijn ingezet om de registratiewerkzaamheden terug te dringen, er ook daadwerkelijk voor zorgen dat de door hen ervaren registratielast vermindert. Het huidige onderzoek kan gebruikt worden als een eerste meting waarop voortgebouwd kan worden.

\section{NOOT}

$\rightarrow$ Dit artikel is gebaseerd op een vragenlijst ingevuld door 1187 deelnemers van het Nivel Panel Verpleging \& Verzorging. Deze deelnemers werken als verpleegkundige, verzorgende, praktijkondersteuner of begeleider verspreid door het land in diverse zorgsectoren. Ze verlenen allen directe zorg aan cliënten. Zie het volledige rapport op www.nivel.nl: Verest, W, Veer, AJE de, Groot, K de, Francke, AL. Kwaliteit en veiligheid van zorg aan cliënten: Verpleegkundigen, verzorgenden, begeleiders en praktijkondersteuners over wat ze nodig hebben voor goede zorg. Utrecht: Nivel; 2019

\section{REFERENTIES}

1. Brinkman, M, Veer, AJE de, Spreeuwenberg, P, e.a. De aantrekkelijkheid van werken in de zorg 2017: cijfers en trends voor verpleegkundigen, verzorgenden, begeleiders en praktijkondersteuners huisartsenzorg. Utrecht: Nivel; 2018.

2. Mooren, $\mathbf{F}$ van der \& Gielen, W. Werknemersenquête zorg en welzijn: uitkomsten $1^{\mathrm{e}}$ meting 2019.

Den Haag: CBS; 2019

3. Hanenkamp, $M$, Heesbeen, $S$, Helm, I van der, e.a. Administratieve belasting langdurige zorg 2019: Uitkomsten onderzoek Berenschot. Utrecht: Berenschot; 2019

4. Veer, AJE de, Groot, $K$ de, Brinkman, M, e.a. Administratieve druk: méér dan kwestie van tijd. Utrecht: Nivel; 2017.

5. V\&VN (z.d.). Digitale verslaglegging. www.venvn.nl/Themas/Digitaleverslaglegging\#Overdragen-vangegevens-97

6. VWS. (Ont)Regel de Zorg: actieplan. Den Haag: Ministerie van VWS; 2018. www.ordz.nl 